MÓCZÁR JÓZSEF

\title{
Kornai János és a neoklasszikus versus intézményi közgazdaságtan
}

Kornai János Anti-equilibrium címü múvében elutasította a walrasi egyensúlyt, és csak a nem egyensúlyi állapotok vizsgálatát tekintette valósághünek. A statikus általános egyensúlyi modellt 1971-ben, akkor még zseniálisnak számító ötlettel stacionárius modellként értelmezte, ami elvezetett a féloldalas, aszimmetrikus, disequilibriumi állapotokhoz. Kutatását az a meggyőződés irányította, hogy a valóságnak és az elméletnek integrált egységet kell alkotnia. A neoklasszikusok nem fogadták el anti-equilibrium-elméletét, ami Kornait arra késztette, hogy fáradhatatlanul további bizonyításokat adjon. A cikk ezt az izgalmas és nemes küzdelmet új megvilágításban, tudományelméleti összefüggésben és a stacionárius modellt newtoni dinamikában értelmezve vizsgálja.

Journal of Economic Literature (JEL) kód: B1, C, D5, E13, E14.

\section{A világhírü kutatás kezdete}

Kornai János valósággal berobbant a magyar közgazdaság-tudományba, ráadásul a középpontjába, amikor kandidátusi tézisében (Kornai [1957]) bátran bírálta a magyar kommunista állam túlzottan központosított gazdaságirányítását. Szerencsés és meghatározó volt tudományos pályáján, hogy két évvel később az Oxford University Press, a világ egyik vezető tudományos könyvkiadója megjelentette disszertációját (Kornai [1959]). Ilyen esetben mondjuk, hogy jó időben jó helyen és föleg jó kezekbe, Anthony de Jasay, ${ }^{1}$ majd John R. Hicks gondozásába került Kornai angol nyelvű diszszertációja Angliában (Kornai [2005] 121. o.), ami kellett a világhírhez. Addig szinte csak a „munkásosztály bibliája”, Marx Tőkéje volt az egyetlen komoly közgazdasági könyv, amelyet tanulmányozott. Marx könyve nem könnyű olvasmány, feltételezi a klasszikus közgazdászok elméleteinek ismeretét, hiszen Smith, Ricardo, Malthus stb.

\footnotetext{
${ }^{1}$ Anthony de Jasay (Jászay Antal) magyar származású közgazdász és liberális filozófus, aki jelenleg Franciaországban él.
}

Móczár József a Budapesti Corvinus Egyetem egyetemi tanára, a Magyar Tudományos Akadémia doktora (e-mail: jozsef.moczar@uni-corvinus.hu).

A kézirat első változata 2018. február 9-én érkezett szerkesztőségünkbe.

DOI: http://dx.doi.org/10.18414/KSZ.2018.3.229 
politikai gazdaságtanát kritizálta kíméletlenül, miközben a saját gazdaságelméletét kidolgozta. Viszont Kornai tehetségét igazolja, hogy pusztán Marx olvasásával és a hazai tapasztalat feldolgozásával olyan disszertációt írt, amely felkeltette a patinás angol kiadó és a nyugati tudományos körök figyelmét.

A Tőke éles kritikai hangvétele a politikai gazdaságtannal szemben mintaként szolgált Kornai kandidátusi tézisében. Disszertációja sikerét az akkori magyar valóság őszinte és bátor feltárásának köszönhette, ami egyúttal a marxizmussal való szakítását is eredményezte. ${ }^{2}$ A politikai pálya feladása után elhatározta, hogy a nyugati közgazdászszakmához kíván tartozni (Kornai [2005] 134. o.). Ugyanakkor világosan látta, hogy csak akkor lehet sikeres kutató, ha a szocialista rendszert vizsgálja nyugati gazdaságfilozófiával és matematikai módszerekkel. Ebben igazolták őt Lipták Tamással közösen írt cikkei a szocialista vállalat nyereségérdekeltségének matematikai vizsgálatáról (Kornai-Lipták [1962/2013]), majd a népgazdaság távlati tervezési feladatainak megoldására kidolgozott kétszintű tervezésről (Kornai-Lipták [1965/2013]). Mindkét cikk elöször az Econometricában jelent meg angol nyelven, ami növelte ambícióját újabb és újabb kutatásokra, ${ }^{3}$ és ami meghozta számára a világhírt a matematikai közgazdaságtanban is.

\section{Anti-equilibrium - a valóság és az elmélet egybeesése}

Kéziratban már 1968-ban olvasható volt Kornainak a gazdasági rendszerelméletről és az általános egyensúlyelméletről szóló sajátos megközelítése, az Antiequilibrium (Kornai [1968]). E kéziratát három évvel később követte a téma részletes kifejtése könyv alakban (Kornai $[1971 b])$. Összes kutatása közül ez volt a legambiciózusabb, az ebben felvetett kritikai problémák teljesebb megoldása vonul végig a mai napig a különböző közbeeső kutatásaiban valamilyen mértékben és teszi teljessé a témában legutóbb írt könyvében (Kornai [2014]). Ebben az Arrow-Debreu [1954/1979] modellel, a General Equilibriummal (továbbiakban GE) szemben az Anti-Equilibrium (továbbiakban AE) kritikai észrevételeit már statisztikai adatokkal, tényekkel is alátámasztja.

Az Anti-equilibriumot megelőzően a piaci jelenségekről, a nyomásról és szívásról írt elemzést (Kornai [1971a]), amelyet két évvel később követett Martos Béla matematikussal közösen írt cikke (Kornai-Martos [1971]) a gazdasági rendszerek autonóm szabályozásáról. Ezek a cikkek kevésbé nyerték el a közgazdászszakma

\footnotetext{
${ }^{2}$ Kitünően ráérzett, hogy a nyugati tudományos köröket legjobban az érdekli, hogy mi történik Kelet-Európában, a vasfüggöny mögött, s nem esett abba a hibába, mint sok (hazai) közgazdász (sikertelen matematikus) még ma is, hogy csak a nyugati elméleteket és modelleket másolja, nyugati közgazdasági alapismeretek nélkül.

${ }^{3}$ Természetesen nem akkora sikerként, de jómagam is hasonlót éreztem, amit Kornai érezhetett, hiszen a Metroeconomicában az 1990-es években két cikkem is megjelent, ráadásul az egyik leading paperként, ami számomra az Oszakai Egyetem ISER által 1994-ben adományozott közgazdasági PhDfokozat elnyerését is jelentette. Érdekes, hogy közgazdaság-tudományból az Egyesült Államokban - a Harvard kivételével - általában könnyebb PhD-fokozatot szerezni, mint Japánban, viszont természettudományokban fordított a helyzet.
} 
tetszését, és később Kornai is elismerte, hogy ez a kutatási irány másokat sem győzött meg eléggé.

Kornai Erőltetett vagy harmonikus gazdasági növekedés címü könyve (Kornai [1972]) az Anti-equilibrium előtti, de végül is az abból kimaradt kutatásait tartalmazza. Meglehetősen eklektikus a témája: a Szovjetunió 1920-as években tervgazdaságának eröltetett növekedését, majd az elméleti, hosszú távon hatékony növekedést modellező, az 1960-1970-es években a tőkés országokban kidolgozott, úgynevezett turnpike (gyorsforgalmi út) elméleteket stb. állította szembe az ágazatok harmonikus növekedésével. ${ }^{4} \mathrm{Ez}$ a müve - a korábbiakhoz hasonlóan - világosan mutatja, hogy Kornai a valóságot a maga életszerüségével, morális értékeivel együtt hajlandó csak modellezni. Az alkotói hitvallása miatt akarva-akaratlanul ezzel a könyvével is szembekerült a föáramú neoklasszikus közgazdasági iskolával. Ennek okát a későbbiekben részletesen tárgyalom.

Az Anti-equilibrium angol nyelvü kiadása már szokatlanul megosztó kritikát kapott, amit Kornai kudarcként élt meg. A legélesebb kritikát Frank Hahn cikke fogalmazta meg az Anti-equilibrium ellenében és az általános egyensúlyelmélet védelmében (Hahn [1973]). A Kornai és Hahn közötti vitát már behatóan vizsgáltam, mind magyarul (Móczár [2006]), mind - újabb gondolatokkal kiegészítve - angol nyelven (Móczár [2017a]), ezért erre a vitára itt most nem térek ki. Helyette szélesebb összefüggésbe helyezem az Anti-equilibriumot, amit az amerikai közgazdaságtan tudományelmélete kínál.

\section{Neoklasszikus versus intézményi közgazdaságtan}

Mint ahogy az Egyesült Államokban két nagy párt van, a Demokrata Párt és a Republikánus Párt, úgy az amerikai közgazdaságtan is két nagy iskolából, a neoklasszikus és az intézményi iskolákból áll.

Az intézményi közgazdaságtan dominálta az amerikai közgazdaságtant legalább az 1940-es évekig, amikor is a fasizmus elől menekülve, Európából a legkiválóbb tudósok áttelepültek Amerikába, akik magukkal vitték a laissez faire-t az angol klasszikus és neoklasszikus művekkel, az európai kultúrát és szellemiséget. Az új amerikai közgazdász-generáció többnyire ezekre a művekre és szellemiségre építette kutatásait. „Olyan szellemi óriások, mint Samuelson és Arrow mutatták az utat, a régi hagyományokat a közgazdasági irodalomból félresöpörték, és a tudományosabb hajlamú tudósok egy kisebb seregét maguk köré gyüjtötték.” (Blinder [1999] 147. o.) ${ }^{5}$ A neoklasszikus iskola lett a mainstream, valószínüleg liberális szemlélete és eleganciája, föleg a vonatkozó orosz matematikai alkalmazásoktól megtisztított (lásd Lefschetz [1953]) elmélete miatt, ${ }^{6}$ ami paradoxon, hiszen a valós közgazdasági kérdések meg-

\footnotetext{
${ }^{4}$ Lényegében ez utóbbit modelleztük Jinkichi Tsukuival, reducibilis struktúra mellett, Japán inputoutput adatain (Móczár-Tsukui [1992]).

${ }^{5} \mathrm{Az}$ angol nyelvű idézeteket saját fordításban közlöm.

${ }^{6}$ A Cowles-bizottság, a Bourbaki-iskola és David Hilbert axiomatikus matematikája is elengedhetetlen szerepet játszott a neoklasszikus (amerikai) közgazdasági gondolkodás formálásában (részletekért lásd Móczár [2008]).
} 
oldásában a relevanciát az intézményi közgazdaságtan adta. ${ }^{7}$ De mik is a főbb jellegzetességei, a neoklasszikus és az intézményi közgazdaságtannak, tanításaikban és kutatásaikban miben térnek el?

A neoklasszikus közgazdaságtan, amely absztrakt feltevéseivel, axiomatikus formalizmusával, a newtoni mechanikára épülő matematikájával a valóságban nem létező párhuzamos világ pillanatnyi összefüggéseit, majd determinisztikus és sztochasztikus dinamikáját kutatja és ex ante modellezi, a 19. század utolsó harmada és a 20. század intellektuális terméke. Dinamikus modelljeiben elfogadja a klasszikus közgazdászok fatalista intuícióját, amit majd Hayek [1944/1991] tovább erősít, a kezdeti feltételektől független, hosszú távon előálló egyensúlyt, ráadásul véleményem szerint helytelenül azonosítva azt az ergodikus hipotézissel (Móczár [2017b]). A neoklasszikus közgazdaságtan a liberális laissez faire filozófiával a fizika és a matematika legújabb eredményeit követve fejlődött. Kérdésfeltevéseik magvát a klasszikus közgazdaságtan esszenciái nyújtották további komplexebb vizsgálatokra a matematika és fizika korának megfelelő legújabb eredményeivel. ${ }^{8} \mathrm{Az}$ intellektuális piac mégis a legmagasabbra árazza be az emberi elme e területen elért konzisztens eredményeit a fejlett nyugati világ egy részében; ez a mainstream. Nobel-díjjal tünteti ki, annak ellenére, hogy elegáns elméleteinek relevanciája megkérdőjelezhető irreális feltevései és neopozitivista formalizálásai miatt, ${ }^{9}$ az emberiség jólétéhez való hozzájárulásuk vitatható, sőt egyes esetekben alkalmazásuk a valóságban globális pénzügyi-gazdasági világválsághoz vezetett (lásd Móczár [2017b]).

Az intézményi közgazdaságtan a 20. század elejétöl létezik az Egyesült Államokban, addig a klasszikus közgazdaságtan tanait követték. Walton Hamilton fejtette ki, hogy egyedül az intézményi közgazdaságtan képes integrálni a közgazdaságtant, megmutatva, hogy a gazdasági rendszer részei hogyan kapcsolódnak az egészhez (Hamilton [1919] 309-311. o). Hangsúlyozta továbbá, hogy az intézményi közgazdaságtan a fogalmait nem normatív szempontok szerint definiálta, fontosságot tulajdonít a gazdaság és a társadalom intézményrendszerének, a jog és közgazdaság összefüggéseinek, a szabályozásoknak, a szerződéseknek és a bizalom problematikájának, ex post vizsgálatokat folytat, előrejelzésében a bizonytalanság dominál.

Hodgson [2000] a legújabb intézményi kutatások kiterjesztésére a következő - általánosan elfogadott - szempontokat sorolja: 1. az intézményi közgazdászok ragaszkodnak elméleteik gyakorlati relevanciájához, de kutatásaik függetlenek a politikai javaslatoktól; 2. a pszichológia, a szociológia és az antropológia eredményeit kiterjedten felhasználják az emberi viselkedés gazdagabb elemzésére; 3. tanulmányozzák az intézményeket és az intézményi magatartás folyamatait, innovációit és változását;

${ }^{7}$ A hazai matematikus közgazdászok egészen a mai napig hibásan a neoklasszikus iskolát illetik mind az elegáns, mind a releváns jelzőkkel.

${ }^{8}$ Ebben az értelemben csupán átiratok újabb hangszereléssel, hasonlóan Mozart Haydn-átirataihoz.

${ }^{9}$ Feltevéseiket a klasszikus közgazdaságtan irreális feltevései adták. Például a klasszikus közgazdász John Stuart Mill meggyőződéssel hitte (Mill [1844]), hogy konstans népességet és konstans tökeállományt, vagyis a gazdaság stacionárius állapotát minden gazdaságnak szükséges és kívánatos elérnie. Kornai $[1971 b]$ ugyan megengedte a GE stacionárius állapotát, de ezt valójában a statikus GE megfogalmazása nem tenné lehetővé. A további irreális feltevéseket és a neopozitivista formalizálásokat lásd Móczár [2008]. 
4. kutatási tárgya egy természetes környezetben müködő gazdaság, amely nyitott és fejlődő rendszer, technológiai változások befolyásolják, társadalmi, kulturális, politikai és hatalmi összefüggések egy szélesebb halmazába van beágyazva; 5 . „rekonstruktív”, visszafelé irányuló összefüggésen keresztül az intézmények fundamentálisan befolyásolják a gazdasági szereplőket.

Kornaiban az 1960-as évek végére végképp megerösödött az a gondolat, hogy a nyugati közgazdasági szakma része szeretne lenni, a neoklasszikus közgazdaságtan művelői közé akar bekerülni. Ez vezérelte az Anti-equilibriumban, ezt érzékeltette sok vitatható megállapítása is, például: „....a közgazdaságtudomány további fejlődése - ha nem is kizárólagosan, de jelentős mértékben - a matematikai közgazdaságtan haladásától függ” (Kornai [1971b] 22. o.). Vagy: „a közgazdaságtudomány eddig mindössze csak egyetlen iskolát hozott létre, amely a gazdasági rendszerelmélet nézöpontjából írja le a gazdaságot, mégpedig formalizált modell segítségével. Ez a gondolatrendszer a Walras nyomán kialakult általános egyensúlyelmélet.” (Uo. 23. o.) Akkor már matematikai közgazdásznak tartotta magát. Ugyanakkor, szerinte „[A] közgazdaság-elmélet reáltudomány [szemben a társadalomtudománnyal], amelynek tárgya a közgazdasági valóság magyarázata." (Uo. 32. o.) Majd minden kétséget kizáróan sommásan közli az általános egyensúlyelmélet kritikáját: „A modern matematikai egyensúlyelmélet... megállapításai nem verifikálhatók, számos ponton mind feltevései, mind megállapításai nyilvánvalóan ellentmondanak a valóságnak. Az egyensúlyelmélet csupán egy gondolatkísérlet." (Uo. 37-38. o.)

Dicséretes, hogy Kornai konzekvens maradt; a marxizmussal azért szakított, mert a magyar kommunista valóság ékes bizonyítékát adta, hogy a marxizmus nem szembesítette tételeit a valósággal. Kornainak teljesen igaza volt az általános egyensúlyelmélet bírálatában, csak a korábbi szakmai sikerei eufórikus hangulatában és közvetlenül az Anti-equilibrium angol nyelvü kiadása előtt a Stanford és a Yale Egyetemeken kapott elismerő biztatások sürüjében nem látta, hogy a neoklasszikus iskola, amelybe az általános egyensúlyelmélet is tartozik, irreális feltevései következtében a valóságban nem létező, párhuzamos világ összefüggéseit kutatja. A neoklasszikus elmélet eleganciája, modern matematikája egyszerre nagyon vonzó és megtévesztő tud lenni, még azok számára is, akik teljesen tisztában vannak korlátaival, hogy a közgazdasági valóság problémáinak megoldására teljesen használhatatlanok. A fentiekre legjobb példa az a paradox helyzet, hogy Paul A. Samuelson, a neoklasszikus közgazdaságtan egyik legnagyobb képviselöje, éretlen fiatalemberként, 20 évesen, milyen kritikusan látta a neoklasszikus közgazdaságtan irreális feltevéseit, amelyeket később, már érett fejjel, maradéktalanul elfogadott modelljei feltételrendszerében.

„Hősiesen elvonatkoztatok. Mindannyian teljesen egyformák vagyunk. Örökké élünk, tökéletes versenyzők vagyunk, és majdnem tökéletes jövendőmondók. Teljesen alkalmazzuk a rugalmatlan munkakínálatot, rugalmatlan ricardói földkínálattal és (lehetőleg heterogén) tőkejószágokkal dolgozunk. A szubjektív időpreferenciába épített Pigou-Böhm-rátával rendelkezünk, amely diszkontálja minden egyes következő évi független hasznosságot az $1 /(1+\rho)$ tényezővel, ahol $\rho>0$. Hosszú távú egyensúlyban vagyunk, technikai változás vagy népességnövekedés nélkül: a tőkejószágok állományát addig a pontig csökkentjük, ahol a termelés eredményezte összes saját kamatráta 
egyenlő nem lesz $r$-rel, a piaci kamatlábbal; viszont az $r$ egyenlő $\rho$-val, a szubjektív kamatlábbal, ami feltétele a fogyasztói hajlandóságunknak a jövedelem 100 százalékára, nulla nettó tőkeberuházással.” (Samuelson [1968] 5. o.)

Semmi kétség nem férhet hozzá, hogy Kornai kritikai észrevételei az általános egyensúlyelmélettel szemben az intézményi közgazdaságtan célkitűzéseit visszhangozták: ex post vizsgálat, szellemi nyitottság, kritikus gondolkodás és intellektuális öszinteség, a dinamika és a bizonytalanság hangsúlyozása (vö. Keynes [1936/1965]). Ezek kifejtése Kornai szakmai pályájában önálló tanulmányt igényel. Mondanom sem kell, hogy a neoklasszikus és az intézményi közgazdaságtani iskolák élesen szemben állnak egymással. Talán ez váltotta ki Hahn [1973] éles kritikáját az Anti-equilibriummal szemben.

Bár sokakat megtéveszt a fóáram olcsó sikere, viszont Kornai nem engedett az elegáns, de nem a valóságot modellező neoklasszikus közgazdaságtan csábításának, sőt kritizálta, bár ahogyan fogalmaz, nem eléggé. Kutatásai, könyvei és cikkei az intézményi közgazdaságtan hitvallását tükrözik, noha magát soha nem tekintette intézményi közgazdásznak. ${ }^{10}$

A politikus és a tudós szakmai pályája nem egyeztethető össze, ezt világosan látta Kornai, amikor a kutatói pályát választotta 1955 júniusában. ${ }^{11}$ Hasonlóan, nem lehet valaki egyszerre neoklasszikus és intézményi közgazdász. Az intézményi közgazdaságtan követése nem jelenti azt, hogy szakítani kell a kapitalizmus ideológiájával és eszméivel. Kimutatták, hogy 2005-ig közel annyi intézményi közgazdász kapta meg a közgazdasági Nobel-emlékdíjat, mint neoklasszikus közgazdász (Móczár (2017b]), vagyis tudományos presztízse sem kisebb. A mostanában divatos „, heterodox” klaszszifikáció nem a neoklasszikus és az intézményi iskolák egybemosását jelenti (Short Note... [2016]); lényegében intézményi irányzat, multidiszciplináris kutatásokat folytat, és több matematikával cáfolja a neoklasszikus iskola tételeit.

\section{A Kornai-féle disequilibrium és bizonyítása}

Kornai a statikus egyensúlyi modell helyett az általános egyensúlyelméletet stacionárius modellként értelmezte - Samuelson [1947] kinyilvánítottpreferenciaelméletének felhasználásával -, így vezethette be a sajátos egyensúlyi állapotait. ${ }^{12}$

${ }^{10}$ 2005-ben az Arrow-Debreu-modell és a Kornai-kritika című kéziratomban Kornait ex post jelzővel illettem, ami ellen hevesen tiltakozott az egyik közeli matematikus munkatársa. Tiltakozását elfogadtam, és a Móczár [2006] cikkben már tompítottam a jelzőt. Bár tudtam, hogy az ex ante jelző ellentmond Kornai tudományos kutatói törekvésének: a valóság és az elmélet egybeesésének.

${ }^{11}$ A pályamódosítást már korábban, valamikor 1954 vége felé javasolta neki Gimes Miklós: „Nem neked való a politika. Inkább menj el kutatónak, az jobban illik hozzád.” (Kornai [2005] 87. o.)

${ }^{12}$ Ez a zseniális ötlet forradalmian új volt 1971-ben. Elötte egyedül Samuelson értelmezte newtoni dinamikában Keynes [1936/1965] modelljét stacionáriusként, hogy igazolja Keynes introspekcióval megállapított feltételét rendszere stabilitására, nevezetesen azt, hogy a fogyasztási határhajlandóságnak 1-nél kisebbnek kell lennie (Samuelson [1947] 276-283. o.). Ma már többen is éltek ezzel az ötlettel, lásd például Móczár-Krisztin [2006]. 
Azonban - mint Wong [1978] kimutatta - a Samuelson-elmélet hibás. Ezért itt a newtoni dinamikát használom.

A stacionárius modell időbeli állandóságot fogalmaz meg egy rendszerre, azt is mondhatjuk, hogy a dinamikus modell egyensúlyi állapotát leíró rendszer. Ha a szerzők sztochasztikus dinamikát vizsgálnak, akkor pedig stacionárius folyamatról beszélnek. ${ }^{13}$ Ha egy rendszer stacionárius állapotban van, akkor mint állapot ott marad az idők végtelenségéig, hacsak nem éri valamilyen külső sokk. E fogalmi tisztázás azt is megmondja, hogy hogyan állíthatunk elő stacionárius modellt egy dinamikus modellből. A technika a lehető legegyszerübb: diszkrét idejü modell esetében a változó két egymást követő időponthoz tartozó értékeinek különbségét nullának vesszük, míg folytonos esetben a változó pillanatnyi változását elimináljuk a rendszerből. Ezzel kiküszöböltük a modellből a dinamikát, amivel a rendszer pillanatnyi egyensúlyi állapotát határoztuk meg.

Ezek után már a statikus modell definíciója is világos: olyan egyenlet vagy egyenletrendszer, amelyben az összefüggésekben lévő „változók” nem függnek az időtől, vagyis a „változók” az ismeretlenek. ${ }^{14}$ Fontos hangsúlyozni, hogy semmiképpen sem kötődnek a dinamikához. Ez természetesen nem jelenti azt, hogy az ismeretlenekhez nem rendelhetünk hozzá időt. De ekkor minden ismeretlenhez csak ugyanazt az időpillanatot rendelhetjük hozzá, ezért sok tankönyv a statikus állapotot a gazdaság pillanatnyi állapotának, „fényképének” tekinti. Ebben az értelemben azt is mondhatjuk, hogy a statikus modell, ha az egyenletrendszernek van megoldása, mindig egy pillanatnyi egyensúlyi állapotot fogalmaz meg.

A fentiekből látható, hogy a statikus modell és a stacionárius modell is állapotot, hangsúlyozottan egyensúlyi állapotot írnak le a mainstream neoklasszikus iskola egyensúlyi paradigmájának megfelelően. Joggal merülnek fel újabb kérdések: különbözik-e a statikus modell a stacionáriustól, és ha igen, mennyiben? A válasz: lényegében semmiben sem különbözik, viszont a stacionárius modell esetében, minthogy valamilyen dinamikai rendszerből származik, lehetőségünk van tanulmányozni a gazdaság viselkedését nem egyensúlyi helyzetekben is. És ez a mai modern elméleti közgazdaságtan legújabb paradigmája: hogyan viselkedik a gazdaság nem egyensúlyi helyzetekben? E szemlélet, áttételesen ugyan, de gyökeret eresztett még a játékelméletben is, amikor Nash [1953] a kooperatív játék megoldását a nem kooperatív játék Nash-egyensúlyi pontjaként állítja elő.

Az általános egyensúlyelmélet Walras definíciója értelmében határozza meg az egyensúlyt: a kereslet egyenlő a kínálattal. Kornai az Anti-equilibriumban eltér ettől a definíciótól, rendszerektől függően egy-egy tartós disequilibriumi állapotot tekint egyensúlyinak. A kapitalizmus egyensúlya a túlkínálat melletti aszimmetrikus állapot, a szocializmus egyensúlya a túlkereslet melletti aszimmetrikus állapot. Az utóbbi a hiánygazdaság, a szocializmus valódi egyensúlyi állapota, míg az előbbi a többletgazdaság,

\footnotetext{
${ }^{13}$ Sztochasztikus folyamatokon belül beszélhetünk stacionárius folyamatról: olyan sztochasztikus folyamat, amelynél az eloszlásfüggvények azonosak maradnak a vizsgálati időpontok tetszőleges értékű időeltolódása esetén.

${ }^{14} \mathrm{Az}$ általános egyensúlyi modellt többen is, például Richard H. Goodwin, egyszerű egyenletrendszernek tekintették (Goodwin [1953]).
} 
a kapitalizmus valódi egyensúlyi állapota. Rezignáltan állapítja meg Kornai [2005]: „Maga az alapgondolat - a két rendszerre jellemző féloldalas, aszimmetrikus állapot, vagy a vevő, vagy az eladó erőfölénye - nem tört igazán keresztül.” (200. o.) Ennek okát nem a kétféle egyensúly szokatlan „nyomás” és „szívás” elnevezésekben látta.

Ez az állapot a 0 és $>$ bináris jelekből álló mátrixszal is kifejezhető:

\begin{tabular}{c|cc}
\hline & $S$ & $D$ \\
\hline$S$ & 0 & $>$ \\
$D$ & $>$ & 0 \\
\hline
\end{tabular}

ahol $S$ a kínálatot, $D$ a keresletet jelöli. A mátrix értelmezése kompatibilis a mainstream neoklasszikus iskola matematikai-közgazdasági disequilibrium-elméletével, s kompaktul kifejezi Kornai hiány-és többletgazdaságát is. Normál jószágokra és instabil walrasi egyensúllyal szerkesztett Marshall-keresztből az is világos, hogy a hiánygazdaságot egy alacsonyabb, míg a többletgazdaságot magasabb piaci árszínvonal - beleértve a szolgáltatásokat és a béreket is - jellemzi, amit az empíria és az egyensúlytalansági elmélet is igazol, a valóság és az elmélet egybeesik. ${ }^{15}$

Aki folyamatában figyelemmel kíséri Kornai munkásságát, észreveszi, hogy egyegy eredeti gondolatokat kifejtő müve publikálása előtt több gondolatkísérletet, vázlatot ad közre, szondázza a tudományos világot, vajon jó úton jár-e. Emellett kiváló kutatói attitüddel is rendelkezik: végtelen kitartással védi azokat az eredeti tudományos felvetéseit, amelyekröl szilárdan meggyözödött, hogy helyesek. Tehát várható volt, hogy az Anti-equilibrium kudarcát, pontosabban a kudarc okait, a két rendszer szokatlan egyensúlyi definícióit stb. későbbi műveiben bővebben kifejti. A következő mü, A hiány pedig a szocializmus egyensúlyi (tartós) állapotát, a hiánygazdaságát, kialakulását és annak okait vizsgálta (Kornai [1980]). Világsiker lett, a szocialista országokban élők először kaptak Kornaitól tudományos magyarázatot (árakkal, bérekkel, puha költségvetéssel stb.) a mindennapi életüket megkeserítő jelenségre. A könyv az első állomás az Anti-equilibrium kiegészítésében: „...»A hiány« sok szálon kapcsolódik az »Anti-equilibrium«-hoz, s igyekszik az abban megjelölt kutatási feladatok közül jó néhányat teljesíteni." (Kornai [1980] 28. o.)

A hiány nem vizsgálta a szocialista rendszer politikai struktúráját és ideológiáját. Egyrészt ez, másrészt a Harvard Egyetemen meghirdetett kurzusa volt az indítéka A szocialista rendszer; Kritikai politikai gazdaságtan címü könyve megírásának (Kornai [1993]). A politikai szféra legjellegzetesebb vonásából, a kommunista párt egyeduralmából indul ki. „Végre ebben az értelemben is igazi politikai gazdaságtant írtam." (Kornai [2005] 340. o.) A müben Kornai már teljesen intézményi közgazdász: a szocializmus politikai gazdaságtanát a szociológia, a szociálpszichológia és a politikai filozófia szempontjából vizsgálta, miközben megvilágítja, hogyan tevődik össze az építőkövekből a szocialista rendszer. Megközelítését rendszerparadigmának nevezi. Addig Kornai neoklasszikus elméleti keretben írt, viszont ebben a müben hirtelen az

\footnotetext{
${ }^{15}$ Ez összhangban van Adam Smith azon érvelésével, hogy magasabb árszínvonal gazdagságot (többletgazdaságot) eredményez (Smith [1776/1992]).
} 
intézményi közgazdaságtant követte. A könyv számos elismerést kapott, és Kornai leggyakrabban hivatkozott müve lett, de komoly bírálatok is születtek, néhányan az iskolák közötti hirtelen váltást kifogásolták (lásd például Vahabi [2018]).

Az Anti-equilibriumban kevésbé talált megértésre a másik tartós disequilibriumi állapot, a kapitalizmus többletgazdasága is, a valódi egyensúlyi állapota, ahogyan Kornai nevezi. Ennek kifejtése volt az utolsó feladat, ami az Anti-equilibrium kevésbé érthető megfogalmazásában bővebb kifejtésre szorult. Kornai ekkor már tíz éve élt Harvard-professzorként az Egyesült Államokban, tehát kellő ismerete és tapasztalata volt a kapitalista rendszerről is. Ehhez a projekthez a vázlatokat a Gondolatok a kapitalizmusról címü könyve szolgáltatta 2011-ben. A könyv első két fejezete az innovációt és a dinamizmust (dinamikát), a technikai haladást, a különböző piacokat (termékek és szolgáltatások, munkaerő) és dinamikájukat elemzi, csupa olyan témát, amelyek nem szerepelnek az általános egyensúlyelméletben. Az Anti-equilibrium generálta szakmai életpálya 2014-ben vált teljessé, amikor az Oxford University Press kiadta a Dynamism, Rivalry, and the Surplus Economy címü könyvet (Kornai [2014]). A DRSE-modellt - a könyv címéből szerkesztett betűszót - különböző egyensúlyi iskolákkal összehasonlítva elemeztem 2015-ben, ezért itt most eltekintek elemzésétől (Móczár [2015]).

1993-ban elnyertem a Giovanni Agnelli kutatói ösztöndíjat, és a Sienai Egyetem vendégeként Goodwin modelljeit tanulmányoztam. Abban az időben a Sienai Egyetem volt a közgazdasági dinamika egyik centruma a világon. A közgazdasági tanszéken kutatott és oktatott Richard H. Goodwin, Frank Hahn, Robert Solow, Lionello Punzo stb. Szabadidőnkben sokat beszélgettünk a modern közgazdaságról Frank Hahnnal is. Az ilyen beszélgetések alkalmával felmerült Kornai János Anti-equilibriuma is. Frank Hahn még akkor is elég kritikusan vélekedett erről a müröl. Így természetesnek vettem 2005-ben, az Anti-equilibriumról folyó vitát elemző cikkem írása előtt, hogy megkérdezzem, vajon változott-e a véleménye azóta? A válasz egy személyes e-mailben rövid intelem volt: „Nem túl profitábilis ismét átmenni a parázson.” Dacoltam intelmével, és folytattam a kutatásaimat a GE és az AE összehasonlítására (Móczár [2006]), csakúgy, mint jelen esetben is, e cikk megírásával. Nem bántam meg, mert sokat profitáltam Kornai János szakmai tapasztalataiból és közgazdaságtanából.

\section{Hivatkozások}

Arrow, J. K.-Debreu, G. [1954/1979]: Az egyensúly létezése versenygazdaságban. Megjelent: Arrow, J. K.: Egyensúly és döntés. Válogatott tanulmányok. Közgazdasági és Jogi Könyvkiadó, Budapest, 21-47. o.

Blinder, A. S. [1999]: Economics Becomes a Science - or does it? Megjelent: Bearn, A. (szerk.): Useful Knowledge: The American Philosophical Society Millennium Program. American Philosophical Society, Philadelphia, 141-154. o. 
Goodwin, R. [1953]: Static and Dynamic Linear General Equilibrium Models. Input-Output Relations. Proceeeding of a Conference on Inter-Industrial Relations. Stenfert Kroese, Driebergen, Leiden, 54-87. o.

Hahn, F. [1973]: The Winter of our Discontent. Economica, Vol. 40. No. 159. 322-330. o. https://doi.org/10.2307/2552806.

Hamilton, W. H. [1919]: The Institutional Approach to Economic Theory. American Economic Review, No. 9. Supplement, 309-318. o.

HAYEK, F. A. [1944/1991]: Út a szolgasághoz. Közgazdasági és Jogi Könyvkiadó, Budapest.

Hodgson, M. G. [2000]: What is the Essence of Institutional Economics? Journal of Economic Issues, Vol. 34. No. 2. 317-329. o. https://doi.org/10.1080/00213624.2000.11506269.

Keynes, J. M. [1936/1965]: A foglalkoztatás, a kamat és a pénz általános elmélete. Közgazdasági és Jogi Könyvkiadó, Budapest.

Kornai János [1957]: A gazdasági vezetés túlzott központosítása. Közgazdasági és Jogi Könyvkiadó, Budapest.

Kornai János [1959]: Overcentralization in Economic Administration: A Critical Analyses Based on Experience in Hungarian Light Industry. Oxford University Press, London.

Kornai János [1968]: Anti-equilibrium. Kézirat. Magyar Tudományos Akadémia Közgazdaságtudományi Intézete, Budapest.

KornaI JánOs [1971a]: Nyomás és szívás a piacon. Közgazdasági Szemle, 18. évf. 1. sz. 41-60. o.

KoRnAI János [1971b]: Anti-equilibrium. A gazdasági rendszerek elméleteiről és a kutatás feladatairól. Közgazdasági és Jogi Kiadó, Budapest. Angolul: Anti-equilibrium. On Economic Systems Theory and the Tasks of Research. North-Holland, Amszterdam.

KoRNAI JÁNOS [1972]: Erőltetett vagy harmonikus gazdasági növekedés. Gondolatok a gazdasági növekedés elméletéről és politikájáról. Akadémiai Kiadó, Budapest.

Kornai JÁnos [1980]: A hiány. Közgazdasági és Jogi Könyvkiadó, Budapest.

Kornai János [1993]: A szocialista rendszer. Kritikai politikai gazdaságtan. Heti Világgazdaság Kiadó Rt., Budapest.

Kornai János [2005]: A gondolat erejével. Rendhagyó önéletrajz. Osiris Kiadó, Budapest. Kornai János [2011]: Gondolatok a kapitalizmusról. Akadémiai Kiadó, Budapest.

Kornai János [2014]: Dynamism, Rivalry, and the Surplus Economy. Two Essays on the Nature of Capitalism. Oxford University Press, Oxford-New York, https://doi.org/10.1093/ acprof:oso/9780199334766.001.0001.

KoRNAI JÁNOS-LiptÁк TAMÁs [1962/2013]: Nyereségérdekeltség egyes gazdasági hatásai a szocialista vállalatokra. Matematikai elemzés. Megjelent: Kornai János Válogatott munkái. III. kötet. Központosítás és piaci reform. Kalligram, Budapest-Pozsony, 479-502. o. Eredeti megjelenés: A Mathematical Investigation of Some Economic Effects of Profit Sharing of Socialist Firms. Econometrica, Vol. 30. No. 1. 140-161. o. https://doi.org/10.2307/1911291.

Kornai János-Lipták Tamás [1965/2013]: Kétszintű tervezés. Megjelent: Kornai János Válogatott munkái. III. kötet. Központosítás és piaci reform. Kalligram, BudapestPozsony, 503-531. o. Eredeti megjelenés: Two-Level Planning. Econometrica, Vol. 33. (1965) No. 1. 141-169. o.

Kornai János-Martos BÉla [1971]: Gazdasági rendszerek vegetatív müködése. Szigma, 4. évf. 1-2. sz. 35-50. o.

Lefschetz, S. [1953]: Russian Contributions to Differential Equations. Symposium on Nonlinear Circuit Analysis, Proceedings. Polytechnic Institute of Brooklyn, New York, 68-74. o. Mill, J. S. [1844]: Essays on Some Unsettled Questions of Political Economy. John W. Parker, London. 
MóczÁR József [2006]: Arrow-Debreu-modell és a Kornai-kritika harminc év után. Közgazdasági Szemle, 53. évf. 2. sz. 175-194. o.

MóczÁr József [2008]: Fejezetek a modern közgazdaság-tudományból. Sztochasztikus és dinamikus nemegyensúlyi elméletek, természettudományos közelítések. Akadémiai Kiadó, Budapest.

MóczÁR JózSEF [2015]: Kornai DRSE-elmélete versus általános egyensúlyelmélet. Pénzügyi Szemle, 60. évf. 2. sz. 200-216. o.

Móczár József [2017a]: Arrow-Debreu Model versus Kornai-critique. Athens Journal of Business and Economics, Vol. 3. No. 2. 143-169. o.

MóczÁr József [2017b]: Ergodikus versus bizonytalan pénzügyi folyamatok. II. rész. Neoklasszikus és institucionális közgazdaságtan. Pénzügyi Szemle, 62. évf. 3. sz. 275-293. o.

MóczÁr József-Krisztin Tibor [2006]: A Harrod modell strukturális stabilitása, Szigma, 37. évf. 1-2. sz. 1-31. o.

MóczÁr József-Tsukui, J. [1992]: Balanced and Unbalanced Growth Paths in a Decomposable Economy: Contributions to the Theory of Multiple Turnpike. Economic Systems Research, Vol. 3. No. 1. 211-222. o. https://doi.org/10.1080/09535319200000019.

Nash, J. F. [1953]: Two-person Cooperative Games. Econometrica, Vol. 21. No. 1. 128-140. o. https://doi.org/10.2307/1906951.

Samuelson, P. A. [1947]: Foundations of Economic Analysis. Harvard University Press, Cambridge, MA.

Samuelson, P. A. [1968]: What Classical and Neoclassical Monetary Theory Really Was. The Canadian Journal of Economics, Vol. 1. No. 1. 1-15. o. https://doi.org/10.2307/133458. Sмiтн, A. [1776/1992]: A nemzetek gazdagsága. Kossuth Könyvkiadó, Budapest.

Short Note... [2016]: A Short Note on "Heterodox Economics". Journal of Heterodox Economics, Vol. 1. No. 2. https://doi.org/10.1515/jheec-2015-0005.

VAнавi, M. [2018]: János Kornai and general equilibrium theory. Acta Oeconomica, Vol. 68. No. S1. 27-52. o. https://doi.org/10.1556/032.2018.68.s.4.

Wong, S. [1978]: Foundation of Paul Samuelson's Revealed Preference Theory: A Study by the Method of Rational Reconstruction. Routledge, London, https://doi.org/10.4324/ 9780203462430. 